\title{
“NEW AWFUL CHANGES - THE HUMAN GEOLOGICAL STRATUM REDISCOVERED": ALLOWING ART TO TALK ABOUT THE ANTHROPOCENE
}

\author{
Alex Ubiratan Goossens PELOGGIA
}

\begin{abstract}
This paper proposes a confrontation between geology and art, based on the original artistic production made by the author that represents geological concepts related to the new human geological epoch, the Anthropocene, now under discussion. The proposal confrontation draws upon the classical piece of by Henry De La Beche, Awful Changes, from about 1830, which refers to the question of geological time, and also upon Stephen Jay Gould's Time's Cycle, Time's Arrow (1991), which analyzes this picture, and to Jan Zalasiewicz's The Earth After Us (2008), which deals with the urban geological stratum as it might be found in the future. The art work thus shows the rediscovery of the geological stratum correlative to the "human event" by intelligent "ichthyosauroid" beings who, in a distant geological future, through stratigraphic analysis, observe the particular characteristics of the episode and interpret the culture that produced it. This paper shows how geological concepts can be adequately represented through creative artistic expression, and how classical geological themes may be of interest for contemporary debate on human geological agency.
\end{abstract}

Keywords: Anthropocene; Human Geological Stratum; Geological Art.

\section{RESUMO}

"NOVAS TRANSFORMAÇÕES ESPANTOSAS - O ESTRATO GEOLÓGICO HUMANO REDESCOBERTO”: PROMOVENDO O DIÁLOGO ENTRE ARTE E O ANTROPOCENO. Este trabalho propõe um debate entre geologia e arte, tornado efetivo por uma produção artística original feita pelo autor deste trabalho - e que representa conceitos geológicos relacionados ao tema do Antropoceno, a nova época geológica humana hoje em discussão. A proposta é fundamentada em uma produção clássica de arte geológica (Awful Changes, de Henry De La Beche, feita em 1830), que se refere à questão do tempo geológico, ao livro Time's Cycle, time's Arrow, de Stephen Jay Gould (1991), que analisa essa obra, e ainda ao livro The Earth After Us, de Jan Zalasiewicz (2008), que trata do estrato geológico urbano tal como poderia ser encontrado no futuro. $\mathrm{O}$ trabalho artístico original mostra, assim, a redescoberta por seres inteligentes "ictiossauroides", em um futuro geológico longínquo, do estrato geológico correlativo ao "evento humano", que observam, por meio da análise estratigráfica, as características particulares do episódio e interpretam a cultura que o produziu. Mostra-se, desse modo, como os conceitos geológicos podem ser adequadamente representados por meio da expressão artística criativa, e como temas geológicos clássicos podem ser de interesse para o debate contemporâneo.

Palavras-chave: Antropoceno; Estrato Geológico Humano; Arte Geológica.

Only the artist, never the fool, sees what the wise nature hides.

Filipo Brunelleschi, 1425 (cited by Walker 2005) 


\section{INTRODUCTION}

In a short paper published a few years ago, AUTIN \& HOLBROOK (2012) asked: "Is the Anthropocene an issue of stratigraphy or pop culture?", that is, an issue not only of academic or scientific interest but concerning to common sense, which is able to inform the collective worldview. Because of the peculiar characteristics of the geological and historical epoch in which we live, the answer seems to be: both. This unique characteristic in recognition of a geological epoch in full contemporary development, the only such one produced by the very agents who recognized it - and, thus, bringing to life the famous phrase of Élisée RECLUS (1998): “L’homme est la nature prenant conscience d'elle-même" (Man is nature becoming aware of itself) - indicates to geologists that their work on the formal stratigraphic definition is much more complex and intricate.

This happens not only because the agency of a completely new element in the history of the Earth, that is, humanity, is at stake, but precisely because the understanding of this agency, which is certainly a "human issue", is also rightly claimed by other fields of knowledge, such as archaeology, anthropology, history, geography, social sciences, environmental sciences, and even psychoanalysis and, of course, art. This has not been the case for any other interval of geological time.

These elements are used together by PELOGGIA et al. (2017) in an example within research that works with the particularity of the Anthropocene, in an attempt to understand, in a long historical perspective, the processes of formation and expansion of the urban geological stratum in the east of the State of São Paulo (Brazil): there is a set of associated conditions, geological (tectonic, lithological), geomorphological (denudational and aggradational processes) and hydrographic, that place alternatives and challenges to the human being, to which answers are given and from which choices are made about the location of the urban settlements that derived from social causes, the wellbeing and the mentality of the settlers.

Pictorial art, in turn, can be a source of meaningful information for the analysis and interpretation of landscape transformations derived from human agency, as is literature. Here I take an "image" of a literary description, from Herbert George WELLS, The First Men in the Moon, in which the author describes the landscape of Lympne's locality, in "the Clay part of Kent":
"Outside the doors of the few cottages and houses that make up the present village big birch besoms are stuck, to wipe off the worst of the clay, which will give some idea of the texture of the district. I doubt if the place would be there at all, if it were not a fading memory of things gone for ever. It was the big port of England in Roman times, Portus Lemanus, and now the sea is four miles away. All down the steep hill are boulders and masses of Roman brickwork, and from it old Watling Street, still paved in places, starts like an arrow to the north. I used to stand on the hill and think of it all, the galleys and legions, the captives and officials, the women and traders, the speculators like myself, all the swarm and tumult that came clanking in and out the harbour. And now just a few lumps of rubble on a grassy slope, and a sheep or two - and me!" (WELLS 2003, p. 5)

What a wonderful description of the formation of the human geological stratum! And, moreover, of the interpretation that makes possible the reconstitution of the former cultural landscape, as the objective of archaeological studies!

In my view, as a geologist, it is up to geologists to open up to dialogue and understand the views and contributions of their "humanist" colleagues, including of course the artists, adapting the formal concepts of geological science as a necessity for a better characterization of the Anthropocene, for example, in the evident fact that the stratigraphic record of human agency is diachronous and that, as a correlative record, it also reflects historical and geographical peculiarities that may be obscured by the imposition of an arbitrary temporal limit (see, for example, BAUER \& ELLIS 2018, for an up-todate discussion on the issue).

The "Anthropocene" is indeed an "issue of pop culture", which makes geologists responsible for thinking about the implications of their stratigraphic decisions on other fields of scientific knowledge and cultural common sense. But it also authorizes the other actors in the cultural field to appropriate, reflect and act on the concept. It is in this sense that, as a geologist and also a plastic artist, I present the proposal of this work.

\section{FORMULATING THE PROPOSAL}

In his book The Earth After Us, Jan ZALASIEWICS (2008) formulates the idea that, from now to many millions of years in the future, 
the Earth would be visited by intelligent beings who, among other things, are geologists. They find, in the author's words, a planet in which geography, "to our own human and contemporary eyes, would look oddly familiar, but distorted: as though remodeled by Salvador Dali". Such travelers, when investigating the stratigraphy of the planet, come across a well delimited layer with differentiated characteristics, a true anomaly in relation to the common stratigraphic pattern. This is the narrative of the rediscovery of the geological record produced by humankind, after it has disappeared: the "human event stratum".

This is the starting point of the work proposed in this article, that is, the rediscovery of the human geological stratum. However, the idea will be treated in a different way and by different tools: instead of the literary path, painting will be used, and the image of intelligent beings "rediscovering" the vestiges of the human being will be taken as inspiration, precisely for this reason, in a classical pictorial work that, almost two hundred years ago, was used as a form of criticism of ideas within the field of geology. This is the engraving Awful Changes (Figure 1), by Henry de la Beche - first director of the British Geological Survey and also author of the famous engraving Duria Antiquior: a more ancient Dorset: probably the first, and still an impressive, "paleo-environmental" reconstruction made from paleontological records. And which, it must be noted, was taken up by palaeontologist David Ward, along with the collaboration of the plastic artist Richard Beazley (text not yet published) as the basis for an updated representation.

Awful Changes, dated 1830 and first published by Frank BUCKLAND (1858, $1^{\text {st }}$ ed. 1857) in his book Curiosities of Natural History, in turn, is not a reconstitution, but a "prediction", as is the case of Zalasiewicz's book. In it, the "Professor Ichthyosaurus", the "sapient" representative of this "resurgent" kind of creature, speaks to a class consisting of young ichthyosaur "pupils", themselves with markedly "human"

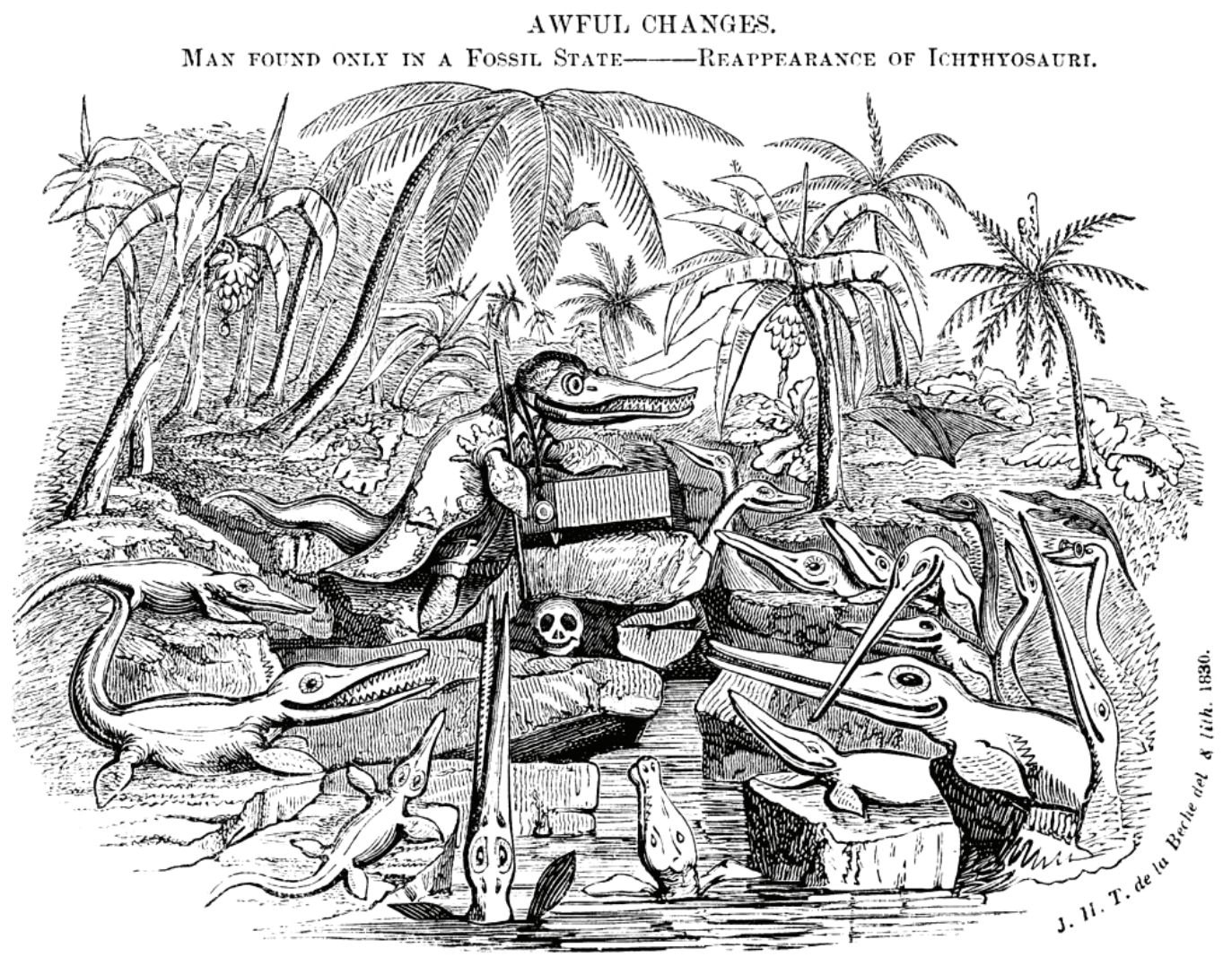

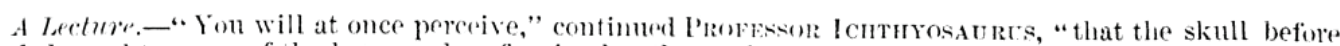
11s belonged to some of the lower order of animals; the teeth are very insignificant, the power of the jaws trifling, and altogether it seems womderful how the creature could have procured food."

FIGURE 1 - The picture "Awful Changes", by Henry de la Beche (made in 1830). From BUCKLAND (1858 [1857]). Image in public domain. 
characteristics, about another peculiar creature found "in a fossilized state": a human being.

The meaning of this allegory was extensively discussed by Stephen Jay GOULD (1991) in the book Time's Arrow, Time's Cycle: myth and metaphor in the discovery of geological time: this is an allusion to the concept of cyclic time used by Charles Lyell in his work Principles of Geology. The discussion proposed by Gould, based on De La Beche's work of art, focuses on the question of the formulation of the concept of geological time itself, a fundamental discussion at the time of the emergence and consolidation of geology itself as a science, and with cultural importance which may only be compared to what it is today occurring within the debate on the Anthropocene. The picture is also commented by Keith THOMSON (2005), in his book Fossils, as a "delightful carton" produced as a reference to Lyell's idea that life proceeds in cycles.

However, the question of the "rediscovery of human remains" is also of great interest for this work. In De La Beche's original work it is a fossil, specifically a skull, that serves as a basis for interpretation: “(...) the skull before us belonged to some of the lower order of animals; the teeth are very insignificant, the power of the jaws trifling, and altogether, it is wonderful how the creature could have procured food". In this work the considered "heritage" will be more comprehensive. The referential elements of the project were presented: the human geological stratum (a lithostratigraphic representative of the Anthropocene) and its possible rediscovery from the present day until a point in the distant future. The method of working will not be absolutely new, since it will be centred on a pictorial representation produced specially to present and to discuss, alternately, the concepts of a human geological event and of the Anthropocene itself, by means of a new view on the "Awful Changes" picture.

Zalasiewicz's own book, which we have quoted, presents such a conception by means of drawings produced from original sketches by the author himself, two of which we reproduce below (Figure 2), in which the relation between the geological conceptions (indicated in writing) and its representation is evident. In the words of this author (personal communication), the drawings represent the spirit of what was being attempted to indicate, rather than being any kind of specific technical illustration. That is, indeed, the spirit.

In fact, the use of drawing images for the illustration of geological concepts dates back a long time. What would be Hutton's "unconformity" without his illustration, in Theory of the Earth? LYELL (1997) also used them in the Principles of Geology. I also cite, by my personal preference, the splendid drawings of Jean-Pierre ALLIX (1996), in the book L'Espace Humain (The Human Space).

Anyway, it might be interesting to say that the creative process of my research - understood as a conscious and rational explanation from a work of art that certainly allows for more complex analyses - arises from a singular convergence, based on an intellectual intuition made possible by a "long process of record formation" - here the geological and archaeological analogy is purposeful - which then became understandable and made sense. This process of convergence and intuition, as masterfully described by Antoine de SAINT EXUPÉRY (1942) in the book Flight to Arras, brought together elements of lived and learned, and reflects options that impose themselves from the ontology of the object considered, but also from the personal perspective of the author. Let's look at what he wrote:

"It is true that a sudden illumination may now and then light up a destiny and impel a man in a new direction. But illumination is vision, suddenly granted the spirit, at the end of a long and gradual preparation. Bit by bit I learnt my grammar. I was taught my syntax. My sentiments were awakened. And now suddenly a poem strikes me in the heart." (SAINT ÉXUPÉRY 1942, p.74)

In the case of the present work, some elements were gathered: the interest in the history of Geology, in particular by Lyell and the painting "Awful Changes", the author's experience in painting and in analysing paintings from the MASP collection and his research on the human geological agency, and also the impression caused by Zalasiewicz's book. Intellectual intuition, of a synthetic character and acting through psychic mechanisms largely unconscious or subconscious, thus made possible a representative "image", arising as an integral mental scene, of the main concept. It was then possible to explain it at the level of scientific analysis. 

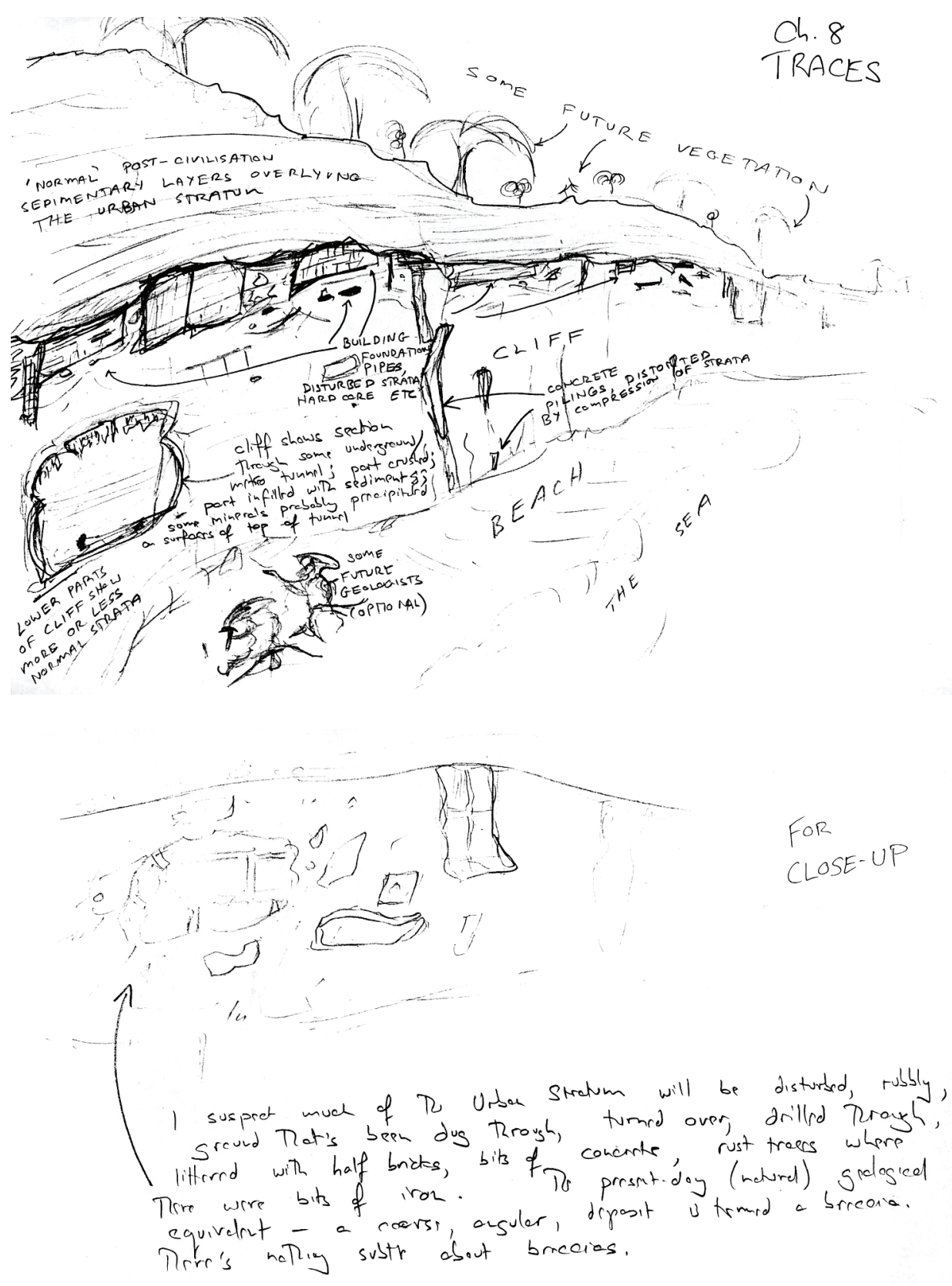

FIGURE 2 - Original sketches by Jan Zalasiewicz for The Earth After Us, which served as the basis for the drawings of Chapters 8 ("Traces") and 9 ("Body of evidence"). Images provided by Jan Zalasiewicz.

\section{RESULTS AND DISCUSSIONS}

\section{Exploring art in search of the Anthropocene}

In the figurative landscape art, which is in principle the modality that shows greater potential for dialogue with the natural sciences, the apprehension and representation of certain elements of interest to the scientist can occur without the intention of the artist, since this refers to the lived space - a concept understood in the sense attributed by Armand FRÉMONT (1976), in the book La Région, Éspace Vécu (The Region, Lived Space) -, representing it mimetically. I will provide two examples pertinent to our subject.

The first example comes from the Italian renaissance work of Piero di Cosimo (1462-1521), from the collection of the São Paulo Museum of 
Art "Assis Chateaubriand" (MASP), "Virgin and Child with the Young Saint John the Baptist and an Angel" (Figure 3). In the background landscape, which is a characteristic that appears precisely in Renaissance painting, one can see, in the right portion, practically naked hillsides, but in which some trees occur. Those who closely observe the curved conformation of the trunks and have some knowledge of the processes of morphogenetic evolution will understand that the occurrence of the surface layer creep phenomenon was clearly being recorded.

Cosimo's work is thus a geological snapshot that freezes in time a process of evolution of the hillslopes, probably of Tuscany, unconsciously represented by the artist, who must have registered the characteristic shape of these twisted trunks in his memory. It is a humanized landscape: there are houses, towers, churches, paths... and nothing permits the consideration that the vegetation is some "untouched paradise". In this context, it is fair to consider the possibility that the processes of evolution of the slopes, evidence of the activity of which has been given, have at least in their intensity, a certain degree of human influence. What about the reliability of the representation of nature in this painting? It is enough to verify the exceptional correlation, shown by REBETEZ (2017), between the yellow caterpillar represented in the left corner of the tondo with the species Acherontia atropos (the "Dead's Head Hawkmoth").

Piero de Cosimo was certainly not concerned with morphogenetic processes, but his experience of the lived space, with the characteristic way of painting the landscape - how else can the idea of a leaning tree be represented? - bequeathed some very geological information. The same can be said about the tondo "Virgin with the Boy and Saint John the Baptist", from the also Florentine Sandro Bottticelli (1445-1510) and Studio, also from the MASP collection (Figure 4). We are thus allowed to think that the phenomenon of creeping was widespread, or at least frequent, on the slopes of Tuscany in the fifteenth century.

However, in the five hundred years after Cosimo's and Botticelli's time, human geological agency became increasingly noticeable on a planetary scale, particularly after the Industrial Revolution, which was the initial reference proposed in 2000 by CRUTZEN \& STOERMER for the beginning of the Anthropocene (although other good denominations already had been suggested). It is this situation that contextualizes the second example, the work "Al Sur del Calvario" by Tomás Sánchez, a master of hyperrealistic landscape painting (for details see, for example, FARTHING 2011). In 1994,

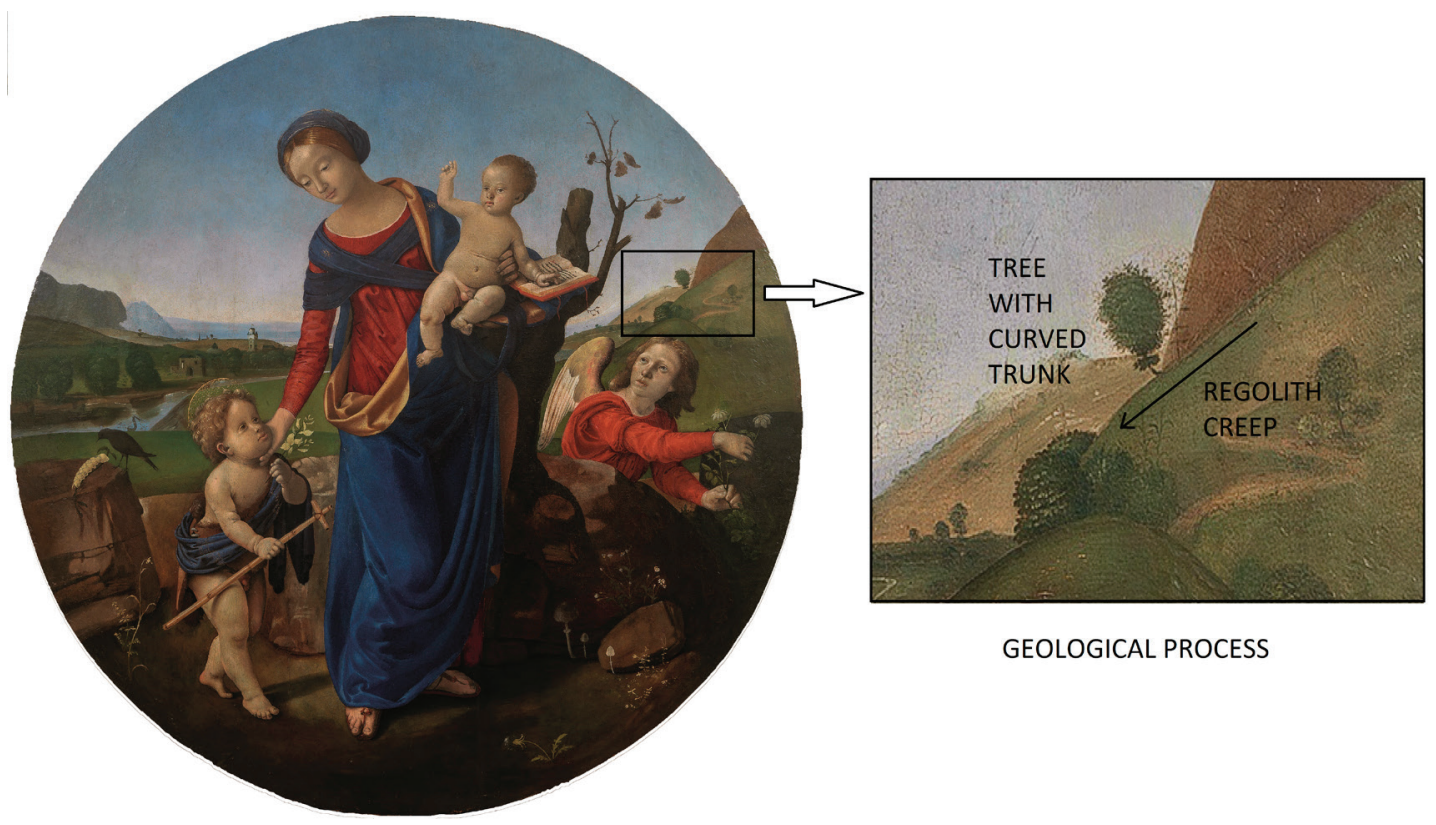

FIGURE 3 - The Piero di Cosimo's tondo "Madonna and Child with Young Saint John the Baptist and Angel" (1500-1510), from the São Paulo Museum of Art “Assis Chateaubriand" (MASP) collection, with the detail of the tree curved trunk. Original photo by Gianfranco Zecca, provided by MASP. 

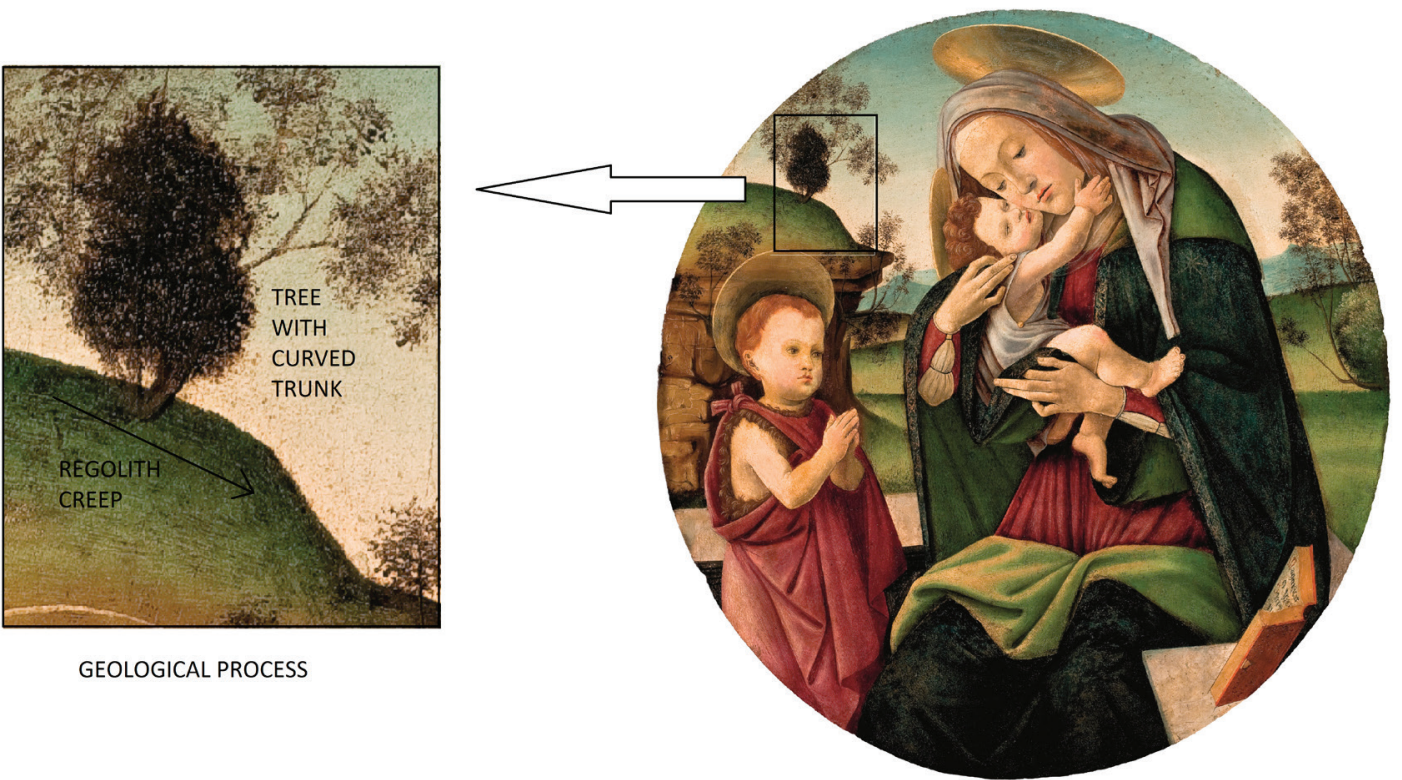

FIGURE 4 - Sandro Botticelli's and Studio tondo "Virgin and Child with the infant St. John the Baptist" (1490-1500), from MASP collection. Original photo by João Musa, provided by MASP.

therefore, before the proposition of the specific concept of Anthropocene, the painting portrays in an amazing way, and by what we understand not deliberate, the concept of the human geological stratum in a formation process, by the accumulation of discarded artifacts like a carpet that covers the entire surface of the landscape.

Finally, if Sánchez's work expresses the full concept of the "Anthropocene", that of Cosimo, with his reference to a process possibly related to the human geological agency, in turn, is consistent with an "Early Anthropocene". The question of how art may have expressed such a transition is yet to be investigated.

Thinking and showing the Anthropocene by means of art

The above analysed examples show one of the effective possibilities for interaction between art and science in the Anthropocene debate, but which is in essence the same basic function of iconography in historical and archaeological studies. However, the alternative proposed here explores the art path as a means of reflection on the theme, the results of which are presented below.

The representation produced for the present work, created by this author in a mixed technique of acrylic on canvas painting and collage (original of $100 \mathrm{~cm}$ by $70 \mathrm{~cm}$ ), reproduced in figure 5 , had started, of course, from the original idea of De La Beche in his organization: here, however, the "ichthyosauroids", intelligent beings that somehow appear on or reach the Earth 100 million years from today are, as Zalasiewicz imagined, not only palaeontologists but stratigraphers. Its central concern is not only to understand the characteristics of the human species through its remains, but the characteristics of the culture from its material records, accumulated in the form of a geological stratum. Here "ichthyosauroid geologists" are also, therefore, archaeologists and anthropologists.

As a honest geologist - with his typical geologicalhammer-,the "ProfessorIchthyosauroid" recognizes some stratigraphic elements that are also observed by his students: the basis of the "human stratum" (which has been referred to as "the A boundary" of the "archaeosphere", concepts proposed by EDGEWORTH 2014, EDGEWORTH et al. 2015) lies upon erosive disconformities or angular unconformities, and sometimes are deposited in paraconformities on its substrate, which is also represented by different materials and shows varying thicknesses. The analysis of these elements strongly suggests that the beginning of the depositional event had a diachronous character.

The ichthyosauroid geologist also recognizes the presence, in underlying typically alluvial 


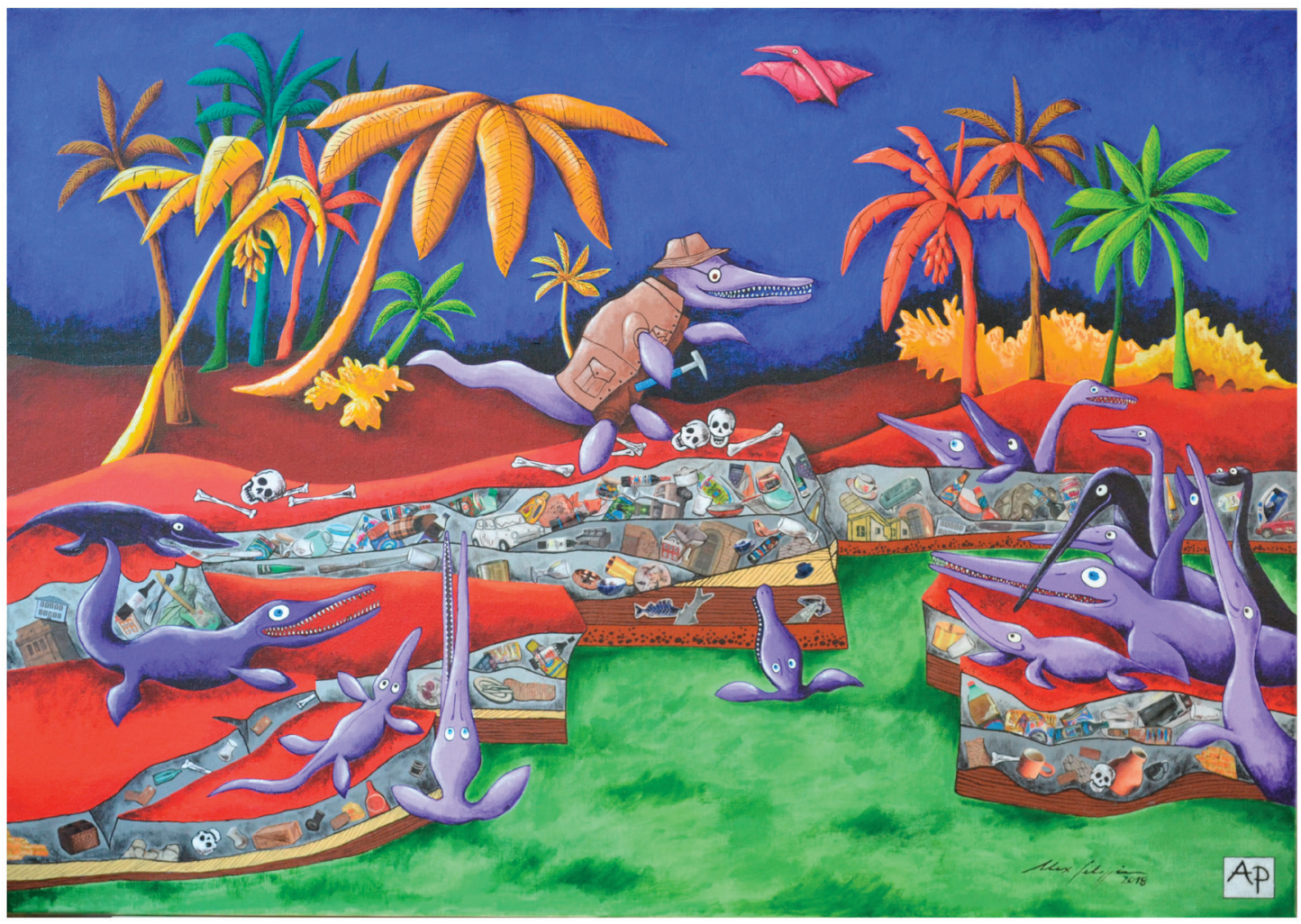

FIGURE 5 - "New Awful Changes - the human geological stratum rediscovered". Acrylic and collage on canvas, $100 \times 70 \mathrm{~cm}$, by Alex Peloggia, 2018. Photo by the author.

sedimentary strata, of some types of artefacts similar to those that would proliferate in the overlying "properly named" human stratum, which allows them to be interpreted as deposits that had been influenced, but not directly produced, by human action (what we now call anthropogenic alluvium, induced technogenic deposits, legacy sediments or post-settlement alluvium).

He closely observes the internal organization of the stratum, which shows vertical structures and cut-and-fill features that generate complex surfaces, particularities of the "cultural layers" that archeologists point out at the level of detailed analysis with the concept of "archaeological stratification" (HARRIS 1991, 2014).

The internal content of the stratum is also highlighted by the ichthyosauroid professor: there are very different types of "fossils" in relation to the underlying layers, many more trace fossils (that is, vestiges of living activity) than those of organic remains: the artefact predominates, which already is now known as a "technofossil" (ZALASIEWICZ et al. 2014). There are also novel materials, mixed at levels of natural materials derived from former geological layers that are clearly indicative of artificial production. This, as the scientist explains, is corroborated by the geochemical analyses carried out, in which are evident anomalies that are not explained by natural geological processes (that is, not influenced by intelligent beings), at least in no known place at any time.

It should be noted that, due to the collage technique used in the production of the picture, we chose the representation of artefacts (technofossils) without taking into account the processes of transformation that occur in the passage from what in archaeology is called "systemic context" to the "archaeological context" (SCHIFFER 1987), much less those discussed by ZALASIEWICZ (2008) with respect to the effects of 100 million years of geological history. This is of course a "poetic license" proper to the artistic representation, which in fact refers sociologically to consumption habits, since the source for the collage was commercial leaflets. Somehow, the evident correlation between the strata represented and the "artifact rug" of "Al Sur del Calvario", by Sánchez, must be perceived.

Anyway, the layers that make up the internal structure of the stratum are irregular, showing even to the most inattentive of ichthyosauroid students 
that the accumulation process did not follow a constant rhythm. On the contrary, as the teacher also indicates, the greater concentration and diversification of artefacts in the upper portions of the stratum is evident. The plastic materials are concentrated in the upper layer, showing, by the law of superposition, that the use of this synthetic material occurred late.

It is at this point that the stratigrapher-geologist becomes an archaeologist: to the amazement of his youthful audience, the diversity of the accumulated artefactual (techno-fossiliferous) record, analysed from its stratigraphic references, is used to try to understand the way of life of the creatures who produced it, that is, its agency and habitus, and even risks interpreting what might have been its motivations, since, as evidently intelligent creatures, they should act not only through the function of basic instincts.

However, to the disappointment of the unquiet class, the lecture had an inconclusive ending. As can be observed, the human layers do not show their contact with the upper layers. Thus, it was not possible for the ichthyosauroid teacher to talk about the history at the end of this stratigraphic event and of the creatures that had produced it: an abrupt boundary, indicating some relatively rapid extinction event, or perhaps a slow decay transition, eventually also diachronous as its start...

In this context, Charles Lyell, in fact, continues to be represented as the central character in the post-anthropocenical version of Awful Changes that is presented here, but for reasons other than those identified by Gould as De La Beche's original intention, to which we have already referred: the critique of the notion of cyclical time. The "repaginated" reference of the new production is rightly proposed with reference to the attention given by Lyell to the question of human agency, present since the first edition of the Principles of Geology (PELOGGIA \& ORTEGA 2016). And his change of position, recognized by Gould, concerning the question of evolution.

It is interesting to note that GOULD (1991), when analysing Lyell's conception of uniformitarianism, comments that "Lyell argued that all past events could be explained by causes now in operation", and that "no old causes are extinct, and no new ones have been introduced". Gould may have been mistaken only about a "new cause": even in the first edition of the "Principles" in 1830, LYELL (1997) already said that: "We may assume that all the present causes were in operation, with the exception of man". Consequently, for the author, "we imagine the state of things to have gone according to the order now observed in regions unoccupied by man". In its original form, Lyellian "uniformitarianism" was already relativized by human agency (PELOGGIA \& ORTEGA 2016). Otherwise, Lyell himself also advanced the idea of the formation of a geological stratum influenced by the human agency, when commenting on the possibilities of preserving remains of ships on the seabed.

Finally, the relation of this work to Lyell is not limited to this: Zalasiewicz himself, in the book that served us as support, refers to the "methodological" uniformitarianism of Lyell, but in the "opposite" sense, that is, "the present is the key of the future":

"In this attempt to reconstruct (or pre-construct, perhaps) the way in which our future explorers might put together the geologically brief history of our species, one needs - as they will need - to understand the planet that could incubate such a species, and them preserve evidence of its existence. This means considering the complicated and rather wonderful workings of the Earth machine that will control our future preservation. These are, of course, exactly the same processes that have produced all the Earth's geological strata and the fossils that they now enclose. There is little reason to believe that they will work any differently in the future." (ZALASIEWICZ 2008, p.5)

\section{FINAL REMARKS}

The novelty of putting dialogue into "art" and "Anthropocene" was not the original idea of this article, except perhaps because the author, as artist and scientist, is the same human person. However, the above-mentioned dialogue is in fact relatively new, appearing, for example, in the article Les strates de la ville de l'Anthropocène, by ZALASIEWICZ et al. (2018), which incorporates pictures by French artist Anne-Sophie Milon, as well as the installation "The mystery of Brunaspis enigmatica", a very sherlockian challenge prepared by Milon and Zalasiewicz for the exhibition "Reset Modernity" (2016), with curatorship by Bruno Latour, in Karlsruhe (Germany).

Be that as it may, this work presents a proposition of knowledge construction not only by interdisciplinary means (in the sense of involving 
more than one scientific discipline), but also culturally, since it involves modes of expression and representation that may be seen, in an unjustifiable way, as unsociable, or even antagonistic, for example by those who forget the fundamental role that the association between science and art played at a time such as the Renaissance of the fifteenth and sixteenth centuries, with the development of the geometric perspective.

I believe, as a geologist, that art represents an exceptional medium for reflection on scientific knowledge and its dissemination; as a plastic artist, in addition I see that science can, as a form of expression of reality, provide valuable elements to nourish artistic creativity, with advantages for culture. I understand that this is the very essence of the concept of "Anthropocene", in a broad sense, in the field of human knowledge.

\section{ACKNOWLEDGEMENTS}

The author thanks Jan Zalasiewicz for his suggestions and the possibility of publishing his original drawings, as well as Brian Begley, Jan Zalasiewicz and Thomas Fairchild for their English linguistic support. Acknowledgments are also due to the São Paulo Art Museum "Assis Chateaubriand" (MASP) for the assignment of the original images of the works from Cosimo and Botticelli. The author also thanks the anonymous reviewers for the valuable suggestions as well as the editors of the Revista do Instituto Geológico for their interest in this research. This research received the "Antonio Teixeira Guerra" award, granted by the Federal University of Rio de Janeiro, for its contribution to the study and analysis on history and resilience of landscape.

\section{REFERENCES}

ALLIX, J.-P. 1996. L'espace humain: une invitacion à la Géographie. Éditions du Seuil, Paris, $420 \mathrm{p}$.

AUTIN, W.J.; HOLBROOK, J.M. 2012. Is the Anthropocene an issue of stratigraphy or pop culture? GSA Today, 22(7): 60-61.

BAUER, A.M.; ELLIS, E.C. 2018. The Anthropocene divide: obscuring understanding of social-environmental change. Current Anthropology, 59(2): 209227.
BUCKLAND, F.T. 1858. Curiosities of Natural History. Richard Bentley, London, $2^{\text {nd }}$ ed., $319 \mathrm{p}$.

CRUTZEN, P.J.; STOERMER, E.F. 2000. The Anthropocene. Global Change Newsletter, 41: 17-18.

EDGEWORTH, M. 2014. The relationship between archaeological stratigraphy and artificial ground and its significance to the Anthropocene. In: C.N. Waters, J.A. Zalasiewicz, M. Williams, M.A. Ellis, A.M. Snelling (eds.). A Stratigraphical Basis for the Anthropocene. London, Geological Society Special Publications, p. 91-108.

EDGEWORTH, M.; RICHTER, D.B.; WATERS, C.; HAFF, P.; NEAL, C.; PRICE, S.J. 2015. Diachronous beginnings of the Anthropocene: the lower bounding surface of anthropogenic deposits. The Anthropocene Review, 2(1): 33-58.

FARTHING, S. 2011. Tudo sobre arte. Sextante, Rio de Janeiro, 576 p.

FRÉMONT, A. 1976. La région, espace vécu. Presses Universitaires de France, Paris, 223 p.

GOULD, S.J. 1991. Time's Arrow, time's cycle: myth and metaphor in the Discovery of Geological Time. Penguin Books, London, $222 \mathrm{p}$.

HARRIS, E.C. 1991. Principios de Estratigrafía Arqueológica. Editorial Crítica, Barcelona, $227 \mathrm{p}$.

HARRIS, E.C. 2014. Archaeological stratigraphy: a paradigm for the Anthropocene. Journal of Contemporary Archaeology, 1(1): 105-109.

LYELL, C. 1997. Principles of Geology: an attempt to explain the former changes of the Earth surface. Penguin Books, London, $472 \mathrm{p}$.

PELOGGIA, A.U.G.; ORTEGA, A.M. 2016. Lyell, a agência geológica humana e o Antropoceno: em busca de uma epistemologia geológica e arqueológica. Revista UNG - Geociências, 15(2): 106-127.

PELOGGIA, A.U.G.; ORTEGA, A.M.; EDGEWORTH, M.; LUZ, R.A. 2017. A expansão do estrato geológico urbano 
(arqueosfera) no Leste do Estado de São Paulo: a relação entre História, Geografia, Geologia e Arqueologia no Antropoceno. Revista Brasileira de Geografia, 62(2): 25-52.

REBETEZ, I.S.B. 2017. Considerations on Piero di Cosimo's tondo in São Paulo: formal analysis, history and iconography. In: K. Barbosa (coord). Piero de Cosimo: restoration. MASP, São Paulo, p. 98-105.

RECLUS, E. 1998. L'Homme et la Terre. La Découverte, Paris, 398 p.

SAINT EXUPÈRY, A. 1942. Flight to Arras. Reynal \& Hitchcock, New York, 225 p.

SCHIFFER, M.B. 1987. Formation processes of the archaeological record. University of Utah Press, Salt Lake City, 428 p.
THOMSON, K. 2005. Fossils: a very short introduction. Oxford University Press, Oxford, $147 \mathrm{p}$.

WALKER, P.R. 2005. A disputa que marcou a Renascença. Record, Rio de Janeiro, 390 p.

WELLS, H.G. 2003. The first men in the Moon. The Modern Library, New York, 240 p.

ZALASIEWICZ, J. 2008. The Earth after us: what legacy will humans leave in the rocks? Oxford University Press, Oxford, 251 p.

ZALASIEWICZ, J., WILLIAMS, M.; WATERS, C.N.; BARNOVSKY, A.D.; HAFF, P. 2014. The technofossil record. The Anthropocene Review, 1(1): 34-43.

ZALASIEWICZ, J.; WATERS, C.; WLILIAMS, M. 2018. Les strates de la ville de l'Anthropocène. Annales. Histoire, Sciences Sociales, 72(2): 329-351.

\section{Author's address:}

Alex Ubiratan Goossens Peloggia - Av. São Luís 71, ap. 304, CEP: 01046-001, São Paulo, SP, Brasil. E-mail: alexpeloggia@uol.com.br.

Manuscript submitted in 3 July 2018, accepted in 30 August 2018. 